\title{
Folic acid for the prevention of neural tube defects
}

\section{Ácido fólico na prevenção dos defeitos do tubo neural}

\section{Editorial}

Neural tube defects (NTDs) are among the most common birth defects, which include anencephaly, spina bifida, and encephalocele. These serious birth defects of the brain and spine are preventable and are significant causes of infant death and childhood disability. It is estimated that there are more than 300,000 NTDs worldwide each year, many of these occurring in low-resource countries. They happen in approximately 1 of 1,000 births in the United States ${ }^{1,2}$.

In Brazil, there is no reliable data regarding general incidence of spina bifida and other NTDs, except for reports of series in specific areas of the country. In the Brazilian Northeastern region, in a tertiary level hospital, the prevalence was five cases for every 1,000 births $^{3}$. A population review for a 14-year period in the South of the country revealed a prevalence of approximately six cases per 10,000 births ${ }^{4}$ and in the Southeast, it was 1.13 per 1,000 live birth 5 .

Results of randomized controlled trials ${ }^{6-8}$ and several observational studies ${ }^{9,10}$ showed that 50 to $85 \%$ of NTDs can be prevented if women consume a folic acid - containing supplement before and during the early weeks of pregnancy in addition to the folate in their diet. Moreover, the Technical Committee and Multidisciplinary Update of the National List of Essential Medicines from the Brazilian Health Ministry recommend for the primary prevention of NTDs daily doses of 400 to $800 \mathrm{mcg}$, at least 30 days before planning to get pregnant and continue throughout the first trimester of pregnancy. In order to provide appropriate pharmaceutical form and concentration for the primary prevention of NTDs, an oral solution of $0.2 \mathrm{mg} / \mathrm{mL}$ folic acid was included in the National List of Essential Medicines ${ }^{11}$.

The recommendations were developed through the collaborative efforts of the fetal and perinatology committee branch of the Brazilian Federation of Gynecology and Obstetrics (FEBRASGO) and external reviewers ${ }^{12}$. Due to the evidence that the prevention of NTDs by folic acid supplementation evolved over time, there are two separate recommendations: one for women at low risk-groups, who are mainly those with no previous history of a NTDaffected pregnancy, and one for females who have had a previous one and are considered at high risk-group for recurrence.

Correspondence

Eduardo Borges Fonsece Universidade Federal da Paraibo Hospital Universitário Lauro Wanderley - 2007 Campus I, s/ Cidade Universitáric Zip code: $58050-000$ João Pessoa (PB), Brazil

Received $03 / 27 / 2013$

Accepted with modifications 05/29/2013
Universidade Federal da Paraíba - UFPB - João Pessoa (PB), Brazil.

2Pontifícia Universidade Católica do Paraná - PUCPR - Curitiba (PR), Brazil; Faculdade Evangélica de Medicina do Paraná - Curitiba (PR), Brazil. ${ }^{3}$ Clínica Obstétrica da Faculdade de Medicina, Universidade de São Paulo - USP - São Paulo (SP), Brazil. 
Of all the children with a NTD, 95\% were born to couples with either no family history of these defects or others risk factors. Evidence to date suggests that a supplement of $400 \mathrm{mcg}(0.4 \mathrm{mg})$ of folic acid prevents the occurrence from 60 to $85 \%$ of NTDs, when it is taken before conception and continued throughout the first 30 days of pregnancy ${ }^{6,7,9,12-16}$.

The working group recommends that all women of childbearing age who are capable of becoming pregnant take $400 \mathrm{mcg}$ of folic acid daily, at least 30 days before planning to become pregnant and continue throughout the first trimester of pregnancy. In addition, women in reproductive age should be counseled on the benefits of folic acid supplementation during any gynecological appointment, such as at the time of their pap smear test, especially if the pregnancy is being planned. Considering the high rate of unplanned pregnancies in Brazil, the group reassures all efforts of public agencies towards the development of comprehensive programs to fortify food and do periodical follow-up of these programs.

\section{High-risk group for neural tube defects}

among couples who had a child with a NTD, the recurrence risk is from 2 to $3 \%$ in subsequent pregnancies ${ }^{1}$. In 1991, the Medical Research Council (MRC) Vitamin Study Group ${ }^{7}$ reported the results of a well-designed, prospective, randomized trial of folic acid supplementation for the prevention of NTDs in pregnancies of women who had a previous child with a NTD, and the CDC published its daily dose recommendations of $4,000 \mathrm{mcg}$ ( $4 \mathrm{mg}$ ) of folic acid.

The results of the MRC study conclusively demonstrated that a daily dosage of $4,000 \mathrm{mcg}$ of folic acid, in addition to folate in the diet, before and during early pregnancy, resulted in a $71 \%$ recurrence reduction of NTDs. The addition of other vitamins to the daily folic acid dose did not reduce the risk further. Use of multivitamins without folic acid did not result in a reduced risk for NTDs. The MRC study did not explore the possible benefit of a dosage lower than $4,000 \mathrm{mcg}$ of folic acid. However, an earlier non-randomized study conducted in the United Kingdom suggested that a lower dosage, $360 \mathrm{mg}$ daily, resulted in a comparable recurrence reduction of NTDs ${ }^{17}$.

The working group recommends that women in the high-risk group who are planning to becoming pregnant take 4,000 mcg of folic acid daily, at least 30 days before and continue throughout the first trimester of pregnancy. In addition, pregnant women should be discouraged from using high doses of folic acid. Particularly, avoiding to take larger doses those that the one defined by the manufacturer, once this could induce an overdose of other vitamins and/or macro or micronutrient, being harmful to maternal and fetal health.

There is no rule for the prevention of other high-risk factors beyond previous history of NTD and patients with seizure disorders, being treated with valproic acid or carbamazepine (risk is approximately 1\%). Nevertheless, those who are planning to become pregnant, and have a relative (as the brother, nephew or niece) with NTD (risk is approximately 0.3 to $1.0 \%$ ), have type 1 diabetes mellitus (risk is approximately $1 \%$ ), or their partner has a NTD (risk may be 2-3\%), should discuss with their physician the potential risk of having an affected child, as well as the advantages and disadvantages of increasing the intake of folic acid daily preconcepcional $400 \mathrm{mcg}$ to $4000 \mathrm{mcg}^{13}$.

Implementing this recommendation may provide the opportunity for primary prevention of over than $70 \%$ of these serious disabling birth defects. Regular and ongoing ingestions of folic acid by women of childbearing age is necessary due to the fact that half of the pregnancies are unplanned, and NTDs occur during the first four weeks of gestation.

Despite the worldwide recommendation, only $16 \%$ of childbearing age women take folic acid and (only about) $5 \%$ of low risk-group take the correct dose of $400 \mathrm{mcg}$.

Hence, this piece of advice should be followed by the implementation of an educational program to prevent NTDs throughout the use of $400 \mathrm{mcg}$ of folic acid supplementation, fortified foods, or a combination of both.

\section{References}

1. Lin S, Herdt-Losavio ML, Chapman BR, Munsie JP, Olshan AF, Druschel CM. Maternal occupation and the risk of major birth defects: a follow-up analysis from the National Birth Defects Prevention Study. Int J Hyg Environ Health. 2013;216(3):317-23.

2. Barbour RS, Macleod M, Mires G, Anderson AS. Uptake of folic acid supplements before and during pregnancy: focus group analysis of women's views and experiences. J Hum Nutr Diet. 2012;25(2):140-7.

3. Pacheco SS, Braga C, Souza Al, Figueiroa JN. Effects of folic acid fortification on the prevalence of neural tube defects. Rev Saúde Pública. 2009;43(4):565-71. 
4. Cunha CJ, Fontana T, Garcias GL, Martino-Roth MG. [Genetic and ambient factors and profile of the newborns with spina bifida]. Rev Bras Ginecol Obstet. 2005;27(5):268-74. Portuguese.

5. Nascimento LFC. Prevalência de defeitos de fechamento de tubo neural no Vale do Paraíba, São Paulo. Rev Paul Pediatr. 2008;26(4):372-7.

6. Czeizel AE, Dudás I. Prevention of the first occurrence of neural-tube defects by periconceptional vitamin supplementation. $\mathrm{N}$ Engl J Med. 1992;327(26): 1832-5.

7. Prevention of neural tube defects: results of the Medical Research Council Vitamin Study MRC Vitamin Study Research Group. Lancet. $1991 ; 338(8760): 131-7$.

8. Central Technical Co-ordinating Unit, ICMR Central Technical Co-ordinating Unit, ICMR. Multicentric study of efficacy of periconceptional folic acid containing vitamin supplementation in prevention of open neural tube defects from India. Indian J Med Res. 2000;1 12:206-11.

9. Berry RJ, Li Z, Erickson JD, Li S, Moore CA, Wang H, et al. Prevention of neural-tube defects with folic acid in China. China-U.S. Collaborative Project for Neural Tube Defect Prevention. N Engl J Med. 1999;341(20):1485-90.

10. Bánhidy F, Dakhlaoui A, Puhó EH, Czeizel AA. Is there a reduction of congenital abnormalities in the offspring of diabetic pregnant women after folic acid supplementation? A population-based case-control study. Congenit Anom (Kyoto). 201 1;51 (2):80-6.

11. Brasil. Ministério da Saúde. Secretaria de Ciência, Tecnologia e Insumos Estratégicos. Departamento de Assistência Farmacêutica e Insumos Estratégicos [Internet]. Relação Nacional de Medicamentos Essenciais - RENAME. Parecer de alteração de dosagem, concentração e forma farmacêutica. Brasília (DF): Ministério da Saúde; 2006 [cited 2013 Mar 27]. Available from: <http://portal.saude.gov.br/portal/arquivos/ pdf/acido_folico.pdf>

12. Federação Brasileira das Associações de Ginecologia e Obstetrícia. Recomendação sobre a suplementação periconcepcional de ácido fólico na prevenção de defeitos de fechamento do tubo neural (anencefalia e outros defeitos abertos do tubo neural) [Internet]. Rio de Janeiro: FEBRASGO; 2012 [citado 2013 Abr 25]. Disponível em: <http://itarget.com.br/clients/febrasgo.org.br/pdf/normativa.pdf>

13. Surén $P$, Roth $C$, Bresnahan $M$, Haugen $M$, Hornig M, Hirtz D, et al. Association between maternal use of folic acid supplements and risk of autism spectrum disorders in children. JAMA. 2013;309(6):570-7.

14. Fescina RH, De Mucio B, Díaz Rossello JL, Martínez G, Durán P, Serruya S. Sexual and reproductive health: guidelines for the phe focused continuum of care of women and newborns. 3rd ed. Montevideo: CLAP/WR; 2011. CLAP/WR. Scientific Publication; $1577-02$.

15. U.S. Preventive Services Task Force. Folic acid for the prevention of neural tube defects: U.S. Preventive Services Task Force recommendation statement. Ann Intern Med. 2009; 150(9):626-31.

16. National Collaborating Centre for Women's and Children's Health. Antenatal care: routine care for the healthy pregnant woman. London: RCOG Press; 2010.

17. Smithells RW, Nevin NC, Seller M, Sheppard S, Harris R, Read AP, et al. Further experience of vitamin supplementation for prevention of neural tube defect recurrences. Lancet. 1983;1(8332):1027-31. 